\title{
PENGARUH BEBERAPA JENIS PAKAN KOMERSIAL TERHADAP KINERJA PRODUKSI KUANTITATIF DAN KUALITATIF AYAM PEDAGING
}

\section{EFFECT OF SOME KINDS OF COMMERCIAL FEED ON QUANTITATIVE AND QUALITATIVE PRODUCTION PERFORMANCE OF BROILER CHICKEN}

\author{
Septiani Anggitasari*, Osfar Sjofjan, dan Irfan Hadji Djunaidi \\ Fakultas Peternakan, Universitas Brawijaya, Malang, 65145
}

Submitted: 16 June 2016, Accepted: 3 October 2016

\section{INTISARI}

Penelitian ini bertujuan untuk mengetahui pengaruh beberapa jenis pakan komersial terhadap kinerja produksi kuantitatif dan kualitatif ayam broiler yang meliputi konsumsi pakan, pertambahan bobot badan, konversi pakan, persentase karkas, deposisi daging dada, mortalitas, indeks produksi (IP), income over feed cost (IOFC), kolesterol daging, dan residu antibiotik ayam pedaging yang mendapatkan pakan komersial yang berbeda. Penelitian ini menggunakan ayam pedaging umur satu hari sebanyak 200 ekor unsexed. Penelitian ini menggunakan Rancangan Acak Lengkap pola searah dengan 4 perlakuan dan 5 ulangan. Ayam diberikan pakan komersial dari beberapa perusahaan (PT. P, PT. M, PT. C, dan PT. W) selama 35 hari masa pemeliharaan. Hasil analisis laboratorium menunjukkan bahwa beberapa jenis pakan komersial ayam pedaging memberikan hasil yang berbeda meliputi bahan kering, protein kasar, serat kasar, lemak kasar, gross energy, kalsium, dan antibiotik. Perbedaan jenis pakan komersial ayam pedaging tidak menunjukkan pengaruh terhadap konsumsi pakan, namun menunjukkan pengaruh $(P<0,05)$ penambahan bobot badan, persentase karkas dan IOFC, serta sangat mempengaruhi $(P<0,01)$ konversi pakan, deposisi daging dada, IP, dan kolesterol daging. Semua pakan komersial memberikan residu oksitetrasiklin dalam daging ayam sebesar <30 ppb. Pengaruh pemberian beberapa jenis pakan komersial ayam pedaging menunjukkan hasil yang berbeda terhadap penampilan produksi secara kuantitas meliputi konsumsi pakan pertambahan bobot badan, konversi pakan, persentase karkas, deposisi daging dada, IP, dan IOFC sedangkan secara kualitas menunjukkan hasil yang berbeda terhadap kolesterol daging dan residu antibiotik. Pakan komersial terbaik terdapat pada pakan PT. M karena pakan dari PT. M memberikan nilai IP dan IOFC yang paling baik.

(Kata kunci: Ayam pedaging, Kinerja produksi, Kolesterol, Pakan komersial, Residu antibiotik)

\begin{abstract}
The study was aimed to investigate the effects of some kinds of commercial feed on quantitative and qualitative production performance of broiler chicken include feed intake, weight gain, feed conversion ratio, mortality, index of production (IP), income over feed cost (IOFC), percentage of carcasses, deposition of breast meat, meat cholesterol, and antibiotic residues. This study used 200 unsexed day old broiler chick which were allocated in Completely Randomized Design and analyzed using one way analysis of variance (ANOVA) with 4 treatments and 5 replications. The birds were fed some of the commercial diets produced by PT. P, PT. M, PT. C, or PT. W from 35 days rearing period. Analysis in the laboratory revealed that different commercial diets did not contain different chemical composition, including: dry matter, crude protein, crude fiber, ether extract, gross energy, calcium, phosphorus and antibiotic residues. Different commercial broiler feeds did not affect feed consumption, but affect $(P<0.05)$ body weight gain, carcass percentage, income over feed cost, and high significantly affect $(P<0.01)$ feed conversion, breast meat deposition, production index, and cholesterol deposition. Oxytetracycline residues in chicken meat from all treatment diets were $<30 \mathrm{ppb}$. Effect of some kinds of commercial feed showed different results on feed consumption, body weight gain, feed conversion, carcass percentage, breast meat deposition, production index, and IOFC, meat cholesterol and antibiotic residue. However, feed from PT. M showed better results, as it gave production index and IOFC values than that of other commercial feeds.
\end{abstract}

(Key word: Antibiotic residues, Broiler chicken, Cholesterol, Feed commercial, Production performance)

\footnotetext{
* Korespondensi (corresponding author):

Telp. +62 81214148338

E-mail: anggita_sitompul@yahoo.com
} 


\section{Pendahuluan}

Kebutuhan protein hewani di Indonesia saat ini sangat tinggi, seiring dengan meningkatnya jumlah penduduk serta kesadaran masyarakat bahwa protein hewani diperlukan dalam memenuhi kebutuhan gizi. Protein hewani menjadi sangat penting karena mengandung asam-asam amino yang mendekati susunan asam amino yang dibutuhkan manusia sehingga akan lebih mudah dicerna dan lebih efisien pemanfaatannya (Bahri et al., 2005). Protein hewani bisa diperoleh dari daging, susu, dan telur. Komoditas peternakan sumber protein hewani yang dapat diandalkan salah satunya adalah ternak unggas terutama ayam pedaging. Data Badan Pusat Statistik (2012) menunjukkan bahwa konsumsi daging ayam ras pedaging masyarakat Indonesia cenderung terus meningkat sebesar 2,27\% per tahun. Rerata konsumsi daging ayam nasional sebesar $3,75 \mathrm{~kg} / \mathrm{kapita} / \mathrm{tahun}$. Angka kebutuhan nasional daging ayam ras pedaging mencapai $3,3 \mathrm{~kg} / \mathrm{kapita} / \mathrm{tahun}$. Total permintaan terhadap daging unggas adalah 4,6 kg per tahun. Kebutuhan protein hewani yang berasal dari daging ayam ras pedaging adalah sebesar $71,7 \%$. Produk utama yang berupa daging merupakan produk yang digemari oleh masyarakat sehingga permintaan kebutuhan daging ayam semakin meningkat dari tahun ke tahun. Keberadaan peternakan ayam pedaging dapat menjadi solusi yang tepat untuk memenuhi kebutuhan protein hewani yang dibutuhkan masyarakat, dengan masa pertumbuhan yang relatif lebih cepat dan memiliki masa panen yang singkat.

Kunci kesuksesan dalam usaha peternakan ayam dipengaruhi oleh tiga faktor utama yaitu penyediaan bibit unggul, pemenuhan kebutuhan pakan dan manajemen pemeliharaan yang baik. Ketiga faktor produksi tersebut merupakan satu kesatuan sistem, apabila salah satu faktor terabaikan atau kurang mendapat perhatian maka penanganan terhadap faktor yang lain tidak dapat memberikan hasil yang maksimal. Pakan adalah salah satu faktor yang sangat penting untuk mencapai suatu keberhasilan produktivitas ayam pedaging secara optimal, oleh karena itu kuantitas dan kualitas pakan hendaknya selalu diperhatikan. Biaya pakan merupakan komponen biaya terbesar yang mencapai $60-70 \%$ dari total biaya produksi ternak unggas.
Ayam pedaging merupakan galur ayam hasil rekayasa teknologi yang memiliki karakteristik ekonomis dengan ciri khas pertumbuhan cepat sebagai penghasil daging, masa panen pendek dan menghasilkan daging berserat lunak, timbunan daging baik, dada lebih besar, dan kulit licin (North dan Bell, 1990). Ayam pedaging memiliki waktu pemeliharaan yang singkat, ayam pedaging umumnya dipanen pada umur $4-5$ minggu dengan bobot badan antara 1,2 - 1,9 kg/ekor yang bertujuan sebagai sumber pedaging. Ayam pedaging memiliki sifat karakteristik badan yang besar, berlemak, memiliki gerak yang lamban dan memiliki pertumbuhan yang cepat, serta menghasilkan daging dengan kandungan protein yang tinggi. Sering sekali menimbulkan persepsi yang keliru di kalangan masyarakat bahwa ayam pedaging dianggap sebagai sumber kolesterol karena ayam pedaging periode finisher cenderung mempunyai lemak tubuh yang tinggi. Kandungan kolesterol dipengaruhi oleh beberapa faktor antara lain faktor genetik, nutrisi pakan, dan obat-obatan. Kadar kolesterol daging ayam pedaging adalah 100 $\mathrm{mg} / 100 \mathrm{~g}$ (Chan et al., 1995) dan $110 \mathrm{mg} / 100 \mathrm{~g}$ (Forrest et al., 1987).

Peternak ayam pedaging lebih sering memberikan pakan komersial dari pada mencampur bahan pakan sendiri. Perusahaan pakan komersial di Indonesia sangat beragam baik jenis produk maupun hasil dari tiap pabrik sehingga harga di pasaranpun tidak sama satu sama lain. Bahan baku impor yang digunakan menyebabkan harga pakan komersial mejadi relatif mahal namun tetap diminati oleh peternak karena mudah didapat dan lebih praktis diberikan pada ternak. Pakan komersial merupakan pakan yang dirancang untuk menghasilkan per-kembangan, pertumbuhan, kesehatan serta penampilan yang optimal karena sudah disusun berdasarkan nilai kebutuhan nutrisi ternak dari kandungan nutrisi yang lengkap dan berkualitas namun dalam pakan komersial digunakan antibiotik sebagai salah satu feed additive. Penggunaan antibiotik dimaksudkan untuk pemacu pertumbuhan (antibiotic growth promoters) karena mekanismenya adalah merangsang pem-bentukan vitamin $B$ kompleks dalam saluran pencernaan oleh mikrobia (Chopra dan Robert, 2001). Antibiotik yang digunakan terus menerus akan menimbulkan efek negatif berupa residu 
dalam karkas ayam pedaging sehingga berbahaya bagi konsumen karena dikhawatirkan akan menjadi resisten terhadap antibiotik. Wuryaningsih (2005) menyatakan bahwa isu keamanan pangan asal ternak yang meresahkan masyarakat antara lain cemaran mikroba pathogen dalam daging seperti residu antibiotik yang dapat menimbulkan resistensi ketika masih mempunyai aktivitas antibakteri, sehingga hal tersebut perlu penanganan bahaya residu antibiotik pada pakan. Keadaan ini menjadi masalah bagi sebagian konsumen, sehingga mereka menginginkan daging ayam yang aman (bebas residu antibiotik) dan sehat (rendah kolesterol).

Prospek karakteristik ayam pedaging yang baik dapat menunjang peran peternakan dalam mewujudkan berkembangnya perekonomian di Indonesia, sehingga perlu dikembangkan sistem peternakan yang efektif dan efisien. Ditinjau dari segi pakan, perlu dilakukan evaluasi mengingat 60-70\% keberhasilan usaha peternakan dipengaruhi oleh pakan. maka dilakukan penelitian terhadap beberapa jenis pakan komersial ayam pedaging yang beredar di Indonesia dengan tujuan sebagai bahan evaluasi serta sumber informasi tentang keamanan pangan asal daging. Evaluasi pakan dalam penelitian ini dilakukan untuk mendapatkan hasil kandungan nutrisi dalam pakan serta pengaruhnya terhadap nilai kuantitas dan kualitas produksi ayam pedaging meliputi konsumsi pakan, pertambahan bobot badan, konversi pakan, persentase karkas, deposisi daging dada, mortalitas, indeks produksi, income over feed cost, kolesterol daging, dan residu antibiotik.

\section{Materi dan Metode}

Materi yang digunakan adalah pakan komersial dari beberapa pabrik pakan yang diambil secara acak dan di dalam pakan terdapat kandungan antibiotik kemudian diberi kode yaitu pakan PT. P, pakan PT. M, pakan PT. C, dan pakan PT. W. Ternak yang digunakan adalah 200 ekor ayam pedaging umur satu hari strain Lohmann Platinum MB 202 unsexed produksi PT. Japfa Comfeed Indonesia.

Penelitian dilaksanakan menggunakan Rancangan Acak Lengkap pola searah dengan 4 perlakuan dan 5 ulangan. Pada tiap ulangan berisi 8 ekor ayam pedaging.
Pemeliharaan ayam pedaging dilakukan mulai umur 1 hari sampai pada umur 35 hari. Perlakuan yang diberikan ke ternak adalah sebagai berikut: $\mathrm{P} 1=$ pakan $\mathrm{PT}$. $\mathrm{P} ; \mathrm{P} 2=$ pakan $\mathrm{PT}$. M; P3 = pakan $\mathrm{PT}$. C; dan $\mathrm{P} 4=$ pakan $\mathrm{PT}$. W.

\section{Prosedur penelitian}

Analisis proksimat dan uji antibiotik.

Pakan komersial ayam pedaging dari beberapa perusahaan yang berbeda dianalisis untuk mengetahui kandungan nutrisi yang ada dalam pakan yang meliputi bahan kering, protein kasar, serat kasar, lemak kasar, gross energy, kalsium, dan fosfor. Uji dilakukan di Laboratorium Nutrisi dan Makanan Ternak, Fakultas Peternakan, Universitas Brawijaya. Kemudian dilakukan uji terhadap kandungan antibiotik oksitetrasiklin dalam pakan menggunakan uji HPLC di Laboratorium Penelitian dan Pengujian Terpadu, Universitas Gadjah Mada.

Pemeliharaan ayam pedaging. Pakan komersial perlakuan diberikan secara ad libitum semenjak ayam berumur satu hari hingga umur panen 35 hari. Pada saat chickin, anak ayam ditimbang bobot badannya terlebih dahulu untuk mengetahui bobot badan awal. Pengukuran variabel konsumsi pakan dan pertambahan bobot badan dilakukan setiap minggu selama pemeliharaan. Variabel persentase karkas dan deposisi daging dada dihitung pada saat panen. Pengukuran variabel kolesterol daging dilakukan di Laboratorium MIPA Universitas Padjajaran dan uji residu antibiotik dalam daging dilakukan di Laboratorium Penelitian dan Pengujian Terpadu, Universitas Gadjah Mada.

\section{Variabel penelitian}

Variabel yang diamati dalam penelitian ini adalah konsumsi pakan, pertambahan bobot badan, konversi pakan, persentase karkas, deposisi daging dada, mortalitas, indeks produksi, income over feed cost, kolesterol daging dan residu antibiotik.

\section{Analisis statistik}

Data yang didapat dari hasil penelitian diolah dengan program Microsoft Excel dan dianalisis menggunakan analisis variansi (ANOVA) dari Rancangan Acak Lengkap pola searah. Apabila menunjukkan perbedaan pengaruh di antara perlakuan maka 
dilanjutkan dengan Uji Jarak Berganda Duncan's.

\section{Hasil dan Pembahasan}

\section{Hasil analisis pakan perlakuan}

Pakan merupakan salah satu faktor penting untuk mendukung pertumbuhan ayam pedaging. Pakan yang diberikan pada ternak ayam pedaging harus mengandung nutrisi yang cukup dan sesuai dengan kebutuhan. Kebutuhan nutrisi ayam pedaging meliputi energi, protein, lemak, serat kasar, vitamin, mineral, dan asam amino.

Tabel 1 menunjukkan kandungan nutrisi dalam pakan P1, P2, P3, dan P4. Hasil uji kandungan protein kasar pada pakan perlakuan sebesar $20,02-22,68 \%$ masih sesuai dengan standar yang dikeluarkan oleh Badan Standar Nasional (2006) yaitu kandungan protein kasar dalam pakan minimal 19\% untuk ayam pedaging. Pakan perlakuan P2 menunjukkan jumlah protein tertinggi yaitu sebesar $22,68 \%$. Protein sendiri berguna untuk membentuk jaringan tubuh, memperbaiki jaringan yang rusak, untuk keperluan berproduksi dan kelebihannya akan diubah menjadi energi.

Hasil uji kandungan lemak kasar dalam pakan perlakuan berkisar antara 5,70-7,79\% masih sesuai dengan kandungan lemak dalam pakan yang dianjurkan oleh Badan Standar Nasional (2006) yaitu kandungan lemak kasar dalam pakan ayam pedaging maksimal adalah $8,0 \%$. Lemak kasar tertinggi terdapat pada pakan perlakuan P4 yaitu sebesar 7,79\%.

Hasil uji kandungan energi metabolis dalam pakan perlakuan adalah antara $3.133,50-3.395,27 \mathrm{kcal} / \mathrm{kg}$ masih sesuai dengan ketentuan Badan Standar Nasional (2006) yaitu kandungan energi dalam pakan untuk ayam pedaging minimal $2.900 \mathrm{kcal} / \mathrm{kg}$. Kandungan energi pakan perlakuan P3 merupakan yang tertinggi dengan hasil $3.395,27 \mathrm{kcal} / \mathrm{kg}$.

Hasil uji kandungan kalsium (Ca) dalam pakan adalah 0,98-1,22\%. Kandungan kalsium tertinggi terdapat pada pakan perlakuan $\mathrm{P} 1$ dengan kandungan $\mathrm{Ca}$ sebesar $1,22 \%$. Hasil uji kandungan fosfor $(P)$ dalam pakan berkisar $0,65-0,74 \%$. Pakan perlakuan P3 memiliki kandungan fosfor paling tinggi sebesar 0,74\%.

Antibiotik yang dianailisis dalam pakan komersial pada penelitian ini adalah antibiotik golongan tetrasiklin. Antibiotik tetrasiklin yang ditambahkan ke dalam pakan ayam pedaging dapat menimbulkan residu dalam daging ayam tersebut (Tabel 1 ).

\section{Pengaruh terhadap konsumsi pakan}

Hasil analisis statistik menunjukkan bahwa perbedaan jenis pakan komersial tidak mempengaruhi konsumsi pakan ayam pedaging (Tabel 2). Konsumsi pakan tertinggi terdapat pada ayam pedaging yang diberi pakan perlakuan P4 dengan konsumsi sebesar 3.313,34 g/ekor. Hal ini diduga disebabkan oleh kandungan energi metabolis pada pakan sebesar pada pakan sebesar $3.133,50 \mathrm{kcal} / \mathrm{kg}$. Pada penelitian ini pakan perlakuan yang diberikan pada ayam pedaging mengandung energi metabolis sekitar 3.133,50-3.395,27 kcal/kg, ternyata memberikan pengaruh konsumsi terhadap ayam pedaging sebesar 3.092,67-3.313,34 g/ekor. Konsumsi pakan pada ayam pedaging dipengaruhi oleh kandungan energi dalam pakan, karena ayam akan terus makan

Tabel 1. Hasil analisis laboratorium beberapa jenis pakan komersial ayam pedaging (determined chemical composition of the experimental diets)

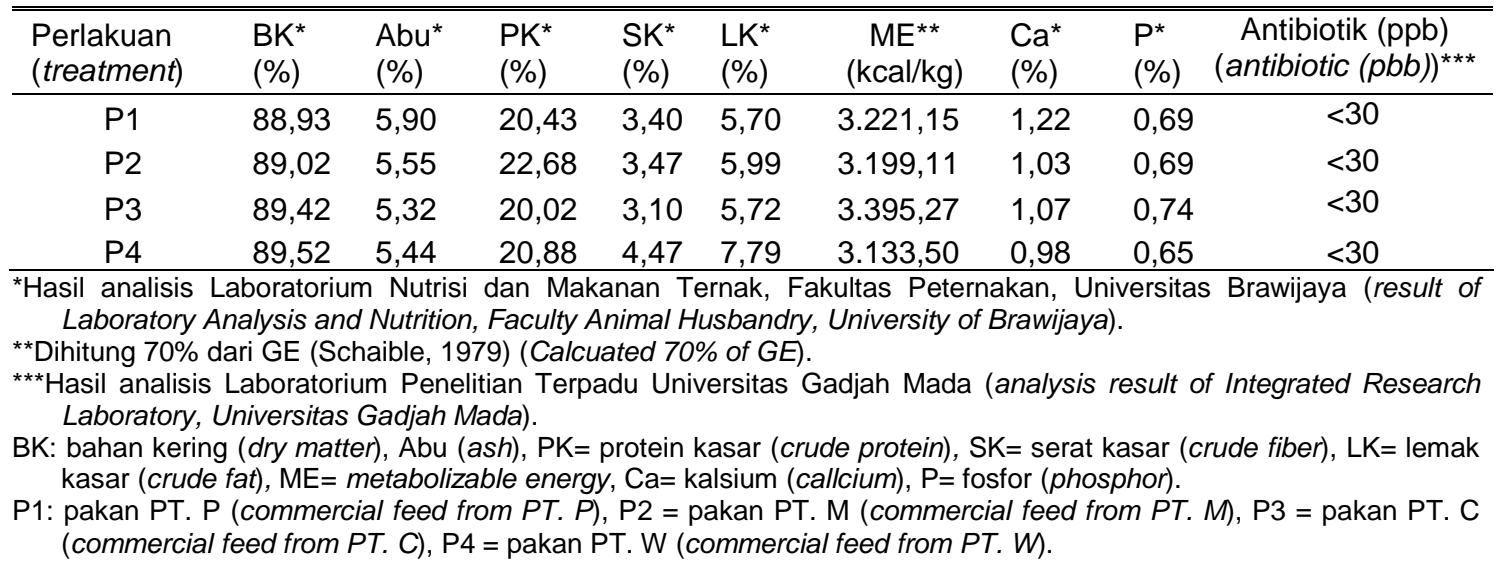


sampai kebutuhan energinya terpenuhi. North dan Bell (1990) menyatakan bahwa faktor utama yang mempengaruhi konsumsi pakan adalah kandungan energi dalam pakan dan keadaan suhu lingkungan. Pakan dengan energi metabolis yang lebih rendah akan memacu ayam pedaging untuk mengkonsumsi pakan tambahan untuk memenuhi kebutuhan energi. Faktor lain yang mempengaruhi konsumsi pakan pada ayam pedaging adalah bobot badan, galur, tingkat produksi, tingkat cekaman, aktivitas ternak, kandungan energi dalam pakan dan suhu lingkungan. Selain itu, bertambahnya umur dan bobot badan selama periode pertumbuhan, konsumsi akan terus meningkat sehubungan dengan meningkatnya kebutuhan zat makanan untuk hidup pokok dan pertumbuhan.

\section{Pengaruh terhadap pertambahan bobot badan}

Hasil analisis statistik menunjukkan bahwa pakan komersial P2 produksi PT. M memberikan pertambahan bobot badan yang terbaik $(P<0,05)$ di antara keempat macam pakan komersial yang diberikan dalam penelitian ini. Ayam pedaging merupakan ayam yang memiliki ciri khas tingkat pertumbuhan yang cepat sehingga dapat dipasarkan dalam waktu singkat. Pertambahan bobot badan diperoleh dengan pengukuran kenaikan bobot badan melalui penimbangan berulang dalam waktu tertentu. Pertambahan bobot badan pada ayam pedaging sangat dipengaruhi oleh kualitas pakan yang dikonsumsi, karena ayam pedaging membutuhkan nutrien yang cukup untuk menunjang proses pertumbuhan pada jaringan tubuh. Ayam pedaging yang diberi pakan perlakuan P2 menunjukkan pertambahan bobot badan paling tinggi sebesar $2.016 \mathrm{~g} / \mathrm{ekor}$, hal ini dipengaruhi oleh kandungan protein dalam pakan perlakuan P2 dengan nilai kandungan sebesar 22,68\%. Widodo (2009) menyatakan bahwa pakan yang dikonsumsi oleh ternak unggas sangat menentukan pertambahan bobot badan sehingga berpengaruh terhadap efisiensi suatu usaha peternakan. Syarat pakan yang dikonsumsi harus berkualitas baik yaitu mengandung zat makanan yang sesuai dengan kebutuhan ternak unggas. Konsumsi pakan juga dipengaruhi oleh temperatur lingkungan, kesehatan ayam, perkandangan, wadah pakan, kandungan zat makanan dalam pakan dan stress yang terjadi pada ternak unggas tersebut. Pakan yang mengandung protein lebih tinggi dari lainnya cenderung memberikan pertambahan bobot badan yang lebih tinggi, sedangkan pakan yang mengandung protein rendah dan dikonsumsi dalam jumlah sedikit dapat menyebabkan terjadinya defisiensi atau ketidakseimbangan asam amino yang menghambat pertumbuhan (Sugiarto, 2008).

\section{Pengaruh terhadap konversi pakan}

Hasil analisis statistik menunjukkan bahwa pakan komersial P2 produksi PT. M memberikan nilai konversi pakan yang paling rendah $(P<0,01)$ di antara keempat macam pakan komersial yang diberikan dalam penelitian ini (Tabel 2). Munt et al. (1995) menyatakan bahwa bentuk pakan untuk menghasilkan konversi pakan yang baik untuk unggas adalah pakan bentuk crumble dan pellet dibandingkan dengan mash. Pakan bentuk crumble dan pellet cenderung mengurangi jumlah pakan yang hilang di dalam litter dibandingkan dengan pakan mash. Pakan bentuk pellet memiliki konversi yang lebih baik dibandingkan dengan pakan bentuk mash yaitu 1,8 berbanding 1,9. Selain itu hal lain yang mempengaruhi konversi pakan adalah kandungan energi metabolis dalam pakan karena akan mempengaruhi konsumsi pada ayam pedaging. North dan Bell (1990) menyebutkan bahwa faktor yang mempengaruhi konversi antara lain adalah energi metabolis dan zat-zat makanan yang terkandung di dalam pakan. Selain pakan, faktor lain yang mempengaruhi konversi pakan adalah genetik, manajemen pemeliharaan dan lingkungan. James (2004) menyatakan bahwa nilai konversi pakan dipengaruhi oleh beberapa faktor antara lain genetik, tipe pakan yang digunakan, feed additive yang digunakan dalam pakan, manajemen pemeliharaan, dan suhu lingkungan. Lacy dan Vest (2000) menyatakan bahwa faktor utama yang mempengaruhi konversi pakan adalah genetik, ventilasi, sanitasi, kulitas pakan, jenis pakan, penggunaan zat aditif, kualitas air, penyakit dan pengobatan serta manajemen pemeliharaan, selain itu meliputi faktor penerangan, pemberian pakan, dan faktor sosial.

Nilai rerata konversi pakan pada ayam pedaging hasil penelitian sebesar 1,60 - 1,72 lebih tinggi dari hasil penelitian yang 
Tabel 2. Pengaruh jenis pakan komersial terhadap kinerja pertumbuhan dan kualitas karkas ayam pedaging

(effects of experimental diets differences on growth performance and quality carcass of broiler chickens)

\begin{tabular}{|c|c|c|c|c|}
\hline \multirow{2}{*}{ Variabel (variable) } & \multicolumn{4}{|c|}{ Perlakuan (treatment) } \\
\hline & P1 & $\mathrm{P} 2$ & P3 & P4 \\
\hline $\begin{array}{l}\text { Konsumsi pakan (g) (feed } \\
\text { intake }(g) \text { ) }\end{array}$ & $3.240 \pm 74,89$ & $3.226 \pm 68,74$ & $3.285 \pm 140,65$ & $3.313 \pm 101,55$ \\
\hline $\begin{array}{l}\text { Pertambahan berat badan }(\mathrm{g}) \\
\text { (body weight gain }(\mathrm{g}) \text { ) }\end{array}$ & $1.937 \pm 44,66^{\mathrm{ab}}$ & $2.016 \pm 62,80^{\mathrm{b}}$ & $1.915 \pm 71,24^{\mathrm{a}}$ & $1.924 \pm 54,56^{\mathrm{a}}$ \\
\hline $\begin{array}{l}\text { Konversi pakan (feed } \\
\text { conversion ratio) }\end{array}$ & $1,67 \pm 0,03^{b}$ & $1,60 \pm 0,02^{a}$ & $1,71 \pm 0,03^{b}$ & $1,72 \pm 0,03^{b}$ \\
\hline $\begin{array}{l}\text { Persentase karkas }(\%) \\
\text { (carcass percentage (\%)) }\end{array}$ & $73,8 \pm 1,10^{\mathrm{ab}}$ & $75,0 \pm 0,71^{b}$ & $74,6 \pm 1,14^{\mathrm{ab}}$ & $73,2 \pm 1,10^{\mathrm{a}}$ \\
\hline $\begin{array}{l}\text { Deposisi daging dada (\%) } \\
\text { (breast meat deposition (\%)) }\end{array}$ & $28,6 \pm 0,89^{b}$ & $29,6 \pm 0,55^{b}$ & $26,6 \pm 0,89^{a}$ & $25,8 \pm 1,64^{a}$ \\
\hline $\begin{array}{l}\text { Indeks produksi (production } \\
\text { index) }\end{array}$ & $311,57 \pm 33,12^{a}$ & $367,03 \pm 15,11^{b}$ & $325,81 \pm 11,74^{b}$ & $303,10 \pm 22,62^{a}$ \\
\hline Income over feed cost (Rp) & $10.092 \pm 522,29^{a b}$ & $10.952 \pm 563,85^{b}$ & $9.284 \pm 1.341,27^{\mathrm{a}}$ & $9.563 \pm 1.341,27^{\mathrm{a}}$ \\
\hline
\end{tabular}

dilaporkan Santoso (2009) bahwa konversi pakan pada ayam ayam pedaging selama 5 minggu pada kandang litter sebesar 1,6. Namun masih dalam batas yang dianjurkan Lesson dan Summer (2000) yaitu pemeliharaan ayam pedaging masih dikatakan efisien bila nilai konversi pakan masih di bawah angka dua.

\section{Pengaruh terhadap persentase karkas}

Hasil analisis statistik menunjukkan bahwa pakan komersial produksi PT. W (P4) memberikan persentase karkas yang paling tinggi $(P<0,05)$ jika dibandingkan persentase karkas ayam yang mendapatkan pakan komersial lainnya (Tabel 2). Nilai persentase karkas ayam pedaging pada penelitian dipengaruhi oleh kandungan nutrisi dalam pakan perlakuan, di mana pakan perlakuan yang dievaluasi mengandung protein $20-22 \%$ dan kandungan energi metabolis sebesar $3.133,50$ - 3.395,27 kcal/kg yang telah mencukupi kebutuhan pada ayam pedaging. Pesti dan Bakalli (1997) menyatakan bahwa ada hubungan linier antara protein, energi, dan persentase karkas. Protein dan energi yang terkandung dalam pakan akan digunakan untuk memproduksi daging dalam tubuh. Soeparno (2005) menyatakan bahwa faktor nutrisi, umur, dan laju pertumbuhan juga dapat mempengaruhi komponen karkas. Selain kandungan nutrisi dalam pakan bobot hidup pada ayam pedaging juga akan mempengaruhi persentase karkas. Safalaoh (2005) menyatakan bahwa persentase karkas dipengaruhi oleh bobot karkas. Bobot karkas ayam ayam pedaging ditunjang oleh bobot hidup akhir yang tinggi pula. Selain disebabkan oleh bobot hidup yang dihasilkan, persentase karkas juga dipengaruhi oleh penanganan dalam proses pemotongan. Faktor-faktor yang dapat mempengaruhi persentase karkas antara lain umur, jenis kelamin, dan bobot badan. Faktor genetik dan lingkungan juga mempengaruhi laju pertumbuhan komposisi tubuh yang meliputi distribusi berat, komposisi kimia, dan komponen karkas. Selain itu nutrisi, umur dan laju pertumbuhan juga dapat mempengaruhi komposisi berat karkas.

Nilai rerata persentase karkas ayam pedaging hasil penelitian berkisar antara 73,2-75\%. Nilai persentase karkas ini lebih tinggi dari pernyataan Pesti dan Bakali (1997) yang menyatakan bahwa persentase karkas ayam pedaging umur 5 minggu berkisar antara 60,52-69,91\% dari bobot hidup.

\section{Pengaruh terhadap deposisi daging dada}

Hasil analisis statistik (Tabel 2) menunjukkan bahwa pakan komersial yang diproduksi PT. C (P3) dan PT. W (P4) memberikan deposisi daging dada yang lebih banyak $(P<0,01)$ daripada pakan komersial yang diproduksi oleh $\mathrm{PT}$. P (P1) dan PT. M (P2).

Nilai deposisi daging dada paling tinggi terdapat pada pakan perlakuan P2 sebesar $28,6 \%$. Hal ini dipengaruhi oleh faktor kandungan nutrisi dalam pakan khususnya 
protein, sehingga menghasilkan bobot karkas yang berbeda dan membuat persentase deposisi daging dada menjadi berbeda pula. Wahju (2004) menyatakan bahwa protein memiliki fungsi yang sangat vital bagi unggas, seperti memperbaiki jaringan yang rusak, pertumbuhan jaringan yang baru, pertumbuhan bulu serta, pensuplai asam amino. Bahij (1991) menyatakan bahwa potongan komersial dada merupakan bagian karkas yang banyak mengandung jaringan otot sehingga perkembangannya lebih banyak dipengaruhi oleh zat makanan khususnya protein. Apabila pemberian pakan dengan nilai nutrisi di bawah standar yang sudah ditentukan akan membuat pertumbuhan ternak kurang optimal. Persentase deposisi daging dada ayam sejalan dengan bertambahnya berat karkas dan berat hidup (Hayse dan Morion, 1973).

\section{Pengaruh terhadap indeks produksi}

Hasil analisis statistik menunjukkan bahwa pakan komersial produksi PT. P (P1) dan PT. W (P4) memberikan indeks produksi ayam pedaging yang lebih tinggi $(P<0,01)$ dibandingkan pakan komersial yang diproduksi oleh PT. M (P2) dan PT. C (P3). Nilai indeks produksi yang lebih tinggi menunjukkan pemeliharaan ternak ayam pedaging yang lebih efisien dan baik. Santoso dan Sudaryani (2009) menyatakan bahwa indeks produksi dapat diperoleh dengan cara sebagai berikut : jika IP $<300$ berarti masuk kriteria kurang, jika 301 - 325 berarti masuk kriteria cukup, jika IP 326 - 350 berarti masuk kriteria baik, jika IP 351 - 400 berarti masuk kriteria sangat baik dan jika IP > 400 berarti masuk kriteria istimewa. Pemeliharaan ayam pedaging pada pakan perlakuan P2 digolongkan dalam kriteria sangat baik karena didukung oleh faktor bobot badan yang dihasilkan mencapai 2.060 g/ekor dengan nilai konversi 1,60 tanpa adanya angka mortalitas pada perlakuan tersebut selama masa pemeliharaan 35 hari, kemudian pada pakan perlakuan P3, P1, dan P4 masuk dalam kriteria cukup. Faktor IP digunakan sebagai acuan karena selain mempertimbangkan bobot badan dan konversi pakan, juga mempertimbangkan tingkat presentase kematian serta lama pemeliharaan (Sjofjan, 2008).
Pengaruh terhadap income over feed cost Hasil analisis statistik pada Tabel 2 menunjukkan bahwa pakan komersial produksi PT. C (P3) dan PT. W (P4) memberikan nilai income over feed cost (IOFC) ayam pedaging yang lebih baik bila dibandingkan dengan pakan komersial produksi 2 perusahaan pakan lainnya $(P<0,05)$. Hal ini disebabkan karena harga pakan yang berbeda dan kandungan yang berbeda sehingga menghasilkan nilai IOFC yang berbeda. Tantalo (2009) menyatakan bahwa nilai IOFC dipengaruhi oleh bobot tubuh akhir, konsumsi pakan, harga pakan dan harga jual ayam pedaging. Sjofjan (2008) menambahkan bahwa tinggi rendahnya nilai IOFC disebabkan oleh adanya selisih yang semakin besar atau kecil pada penjualan ayam dengan biaya pakan yang harus dikeluarkan selama periode pemeliharaan.

\section{Pengaruh terhadap kadar kolesterol daging}

Hasil analisis statistik menunjukkan bahwa pakan komersial yang diproduksi PT. C (P3) dan PT. W (P4) memberikan kadar kolesterol yang lebih rendah $(P<0,01)$ dibandingkan pakan komersial yang diproduksi oleh kedua perusahaan yang lain. Peningkatan kandungan kolesterol dalam daging pada ayam yang diberikan pakan perlakuan P4 dengan kandungan lemak kasar sebesar 7,79\% memberikan hasil kandungan kolesterol paling rendah. Kandungan kolesterol daging yang rendah pada ayam yang diberi pakan P4 diduga karena pada pakan P4 banyak mengandung nabati sehingga tidak mempengaruhi kandungan kolesterol daging, sedangkan pada $\mathrm{PO}$ banyak menggunakan lemak hewani yang berasal dari tepung ikan.

Nilai rerata penelitian ini sesuai dengan pernyataan Saidin (1999) yang menyebutkan bahwa kolesterol di daging ayam berkisar pada 110 mg/100g. Hendrawati (1999) juga menyatakan bahwa kolestrol dalam daging ayam ayam pedaging baik yang berkisar antara 80 sampai 91 mg/100g. Kandungan kolesterol yang dihasilkan pada penelitian lebih rendah dibanding hasil penelitian AlNajdawi dan Abdullah (2002). Hasil penelitian Al-Najdawi dan Abdullah (2002) menyatakan bahwa kandungan kolesterol dalam daging ayam tanpa kulit berkisar antara 133-202 mg/100g berdasarkan bobot kering, 
Tabel 3. Pengaruh penggunaan beberapa jenis pakan komersial terhadap kandungan biokimia daging (effect of commercial feed on biochemical composition of chicken meat)

\begin{tabular}{|c|c|c|c|c|}
\hline \multirow{2}{*}{ Variabel (variable) } & \multicolumn{4}{|c|}{ Perlakuan (treatment) } \\
\hline & P1 & $\mathrm{P} 2$ & P3 & P4 \\
\hline Kolesterol daging (meat cholesterol) (mg/100g) & $79 \pm 0,52^{b}$ & $79 \pm 0,69^{\mathrm{ab}}$ & $78 \pm 0,72^{a}$ & $78 \pm 0,32^{a}$ \\
\hline Residu antibiotik (antibiotic residues) (ppb) & $<30$ & $<30$ & $<30$ & $<30$ \\
\hline
\end{tabular}

sedangkan untuk daging utuh adalah 261-407 $\mathrm{mg} / 100 \mathrm{~g}$ BK.

\section{Pengaruh terhadap residu antibiotik}

Antibiotik yang diuji dalam penelitian ini adalah golongan tetrasiklin karena antibiotic ini sering ditambahkan ke dalam pakan ternak ayam pedaging dengan tujuan untuk menekan pertumbuhan bakteri negatif dan memicu pertumbuhan. Hasil uji HPLC menunjukkan bahwa ayam pedaging yang diberi pakan komersial menghasilkan residu antibiotik golongan tetrasiklin di dalam daging sebesar <30 ppb pada pemberian pakan komersial selama 28 hari dan 35 hari, dapat dilihat pada Tabel 3. Hasil kandungan residu antibiotik dalam daging ayam pada penelitian ini masih sesuai dengan yang dianjurkan Badan Standar Nasional (2005) yang menyatakan batas maksimum residu antibiotik golongan tetrasiklin pada daging adalah sebesar $100 \mathrm{ppb}$.

Yuningsih et al. (2004) menyatakan bahwa tetrasiklin ialah antibiotik yang umum digunakan sebagai obat-obatan veteriner dan diisolasi dari bakteri Streptomyces sp. Penggunaan tetrasiklin sebagai obat-obatan veteriner umumnya dicampurkan ke dalam pakan. Tetrasiklin merupakan antibiotik yang bersifat bakteriostatik dan bekerja dengan jalan menghambat sintesis protein kuman. Tetrasiklin memiliki spektrum yang luas, artinya antibiotik ini memiliki kemampuan melawan sejumlah bakteri patogen. Tetrasiklin merupakan senyawa kristal berwarna kuning dan sedikit larut dalam air. Pada suhu $28^{\circ} \mathrm{C}$ kelarutan tetrasiklin dalam air sebesar $1,7 \mathrm{mg} / \mathrm{ml}$ sedangkan dalam metanol lebih dari $20 \mathrm{mg} / \mathrm{ml}$ (Schunack et al. 1990).

\section{Kesimpulan}

Kualitas kandungan pakan komersial terbaik terdapat pada pakan PT. M karena memiliki kandungan protein yang tinggi.
Pakan perlakuan terbaik terdapat pada pakan PT. M karena memberikan nilai IP dan IOFC yang paling baik. Kandungan kolesterol daging dan residu antibiotik dalam daging pada semua perlakuan masih dalam batas aman untuk dikonsumsi.

\section{Daftar Pustaka}

Al-Najdawi, R. and B. Abdullah. 2002. Proximate composition, selected minerals, cholesterol content and lipid oxidation of mechanically and handdeboned chickens from the jordanian market. J. Meat Sci. 6: 243247.

Badan Pusat Statistik. 2012. Survei Sosial Ekonomi Nasional, Pengeluaran untuk Konsumsi Penduduk Indonesia 2010, Jakarta.

Badan Standar Nasional. 2005. (SNI 01-48682005). Bibit Niaga (Final Stock) Ayam Ras Tipe Pedaging Umur Sehari (DOC).

Badan Standar Nasional. 2006. (SNI 01-39302006). Pakan Anak Ayam Ras Pedaging (Broiler Starter).

Badan Standar Nasional. 2006. (SNI 01-39312006). Pakan Ayam Ras Pedaging Masa Akhir (Broiler Finisher).

Bahij, A. 1991. Tumbuh kembang potongan karkas komersial ayam broiler akibat penurunan tingkat protein ransum pada minggu ketiga keempat. Karya IImiah. Fakultas Peternakan. Institut Pertanian Bogor, Bogor.

Bahri, S., E. Masbulan, dan A. Kusumaningsih. 2005. Proses praproduksi sebagai faktor penting dalam menghasilkan produk ternak yang aman untuk manusia. http://www.pustakadeptan.go.id/publication/p3241054.pdf Diakses pada 10 Agustus 2015. 
Chan, W., W. C. Brown, S. M. Lee and D. H. Buss. 1995. Meat, poultry and game. In: Supplement to Mc Cane and Widdowson's. The Composition of Foods. Published by The Royal society of Chemistry, Cambridge and Ministry of Agriculture, Fisheries and Food, London.

Chopra, I. and M. Robert. 2001. Tetracycline Antibiotiks: mode of action, application, moleculer biology, and epidemiology of bacterial resistances. Microbiology and Molecular Biology Reviews. 62: 232260.

Forrest, J. C., E. D. Aberle, H. B. Hedrick, M. D. Judge and R. A. Markell. 1977. Principles of Meat Sience. W. $\mathrm{H}$. Freman and Co, San Fransisco.

Hayse, P. L. and W. Morion. 1973. Eviscerated field component parts, and meat, skin and bone ratios in the chicken broiler. Poult. Sci. 52: 718-722.

Hendrawati, A. 1999. Penurunan kadar kolesterol broiler dengan penambahan temulawak (Curcumaa xanthorrhizoma Roxb) dalam ransum. Program Pasca Sarjana Institut Pertanian Bogor, Bogor.

James, R. G. 2004. Modern Livestock and Poultry Production. $7^{\text {th }}$ edn. Thomson Delmar Learning Inc., FFA Activities, London.

Lacy, M. and L. R. Vest. 2000. Improving feed conversion in broiler: A Guide Forgrowers.

http://www.ces.uga.edu/pubed/c:793W.html. Accessed 6 December 2015.

Lesson, S. and J. D. Summer. 2000. Production and carcass characteristic of the broiler. Poult. sci. 59: 786-798.

Munt, R. H. C., J. G. Dingle and M. G. Sumpa. 1995. Influence of Feed Form Broiler Performance.

http://www.poultry.org/file://Net/mash dan pellet perbandingan.htm. Accessed 26 Desember 2015.

North, M. O. and D. D. Bell. 1990. Commercial Chicken Production Manual. $4^{\text {th }}$ edn. Van Northland Reinhold, New York.

Pesti, G. M. and R. L. Bakali. 1997. Estimation of the composition of broiler cascasses from their specific gravity. Poult. Sci. 76: 948-951.

Safalaoh, A. C. L. 2005. Body weight gain, dressing percentage, abdominal fat and serum cholesterol of broilers
Suplemen-Ted with a microbial preperation. Afr. J. Food Agric. Nutr. Dev. 6: 204-210.

Saidin, M. 1999. Kandungan kolesterol dalam berbagai bahan makanan hewani. Buletin Penelitian Kesehatan 27: 224230.

Santoso, H. dan T. Sudaryani. 2009. Pembesaran Ayam Pedaging di Kandang Panggung Terbuka. Cetakan Pertama. Penebar Swadaya, Jakarta.

Santoso, U. 2009. Pengaruh tipe kandang dan pembatasan pakan di awal pertumbuhan terhadap performans dan penimbunan lemak pada ayam pedaging. unisexed. Jurnal IImu dan Veteriner 7: 84-89.

Schaible, P. J. 1979. Poultry Feed and Nutirient. $3^{\text {rd }}$ edn. Avi Publishing Co. Inc., Wesport, Connecticut.

Schunack, W., K. Mayer, dan M. Haake. 1990. Senyawa Obat. Edisi kedua. Universitas Gadjah Mada, Yogyakarta.

Sjofjan, O. 2008. Efek penggunaan tepung daun kelor (Moringa Oleifera) dalam pakan terhadap penampilan produksi ayam pedaging. Prosiding Seminar Nasional Teknologi Peternakan dan Veteriner. Fakultas Peternakan. Universitas Brawijaya, Malang.

Soeparno. 2005. Ilmu dan Teknologi Daging. Cetakan Ke-4. Gadjah Mada University Press, Yogyakarta.

Sugiarto, B. 2008. Performa ayam broiler dengan pakan komersial yang mengandung tepung kemangi (Ocimum basilicum). Skripsi Fakultas Peternakan, Institut Pertanian Bogor, Bogor.

Tantalo, S. 2009. Perbandingan performans dua strain broiler yang mengonsumsi air kunyit. Jurnal IImiah IImu-ilmu Peternakan 13: 146-152.

Wahju, J. 2004. Ilmu Nutrisi Unggas. Gadjah Mada University Press, Yogyakarta.

Widodo, W. 2009. Nutrisi dan Pakan Unggas Kontekstual. Universitas Muhammadiyah Malang, Malang.

Wuryaningsih, E. 2005. Kebijakan pemerintah dalam pengamanan pangan asal hewan. Prosiding Lokakarya Nasional Keamanan Pangan Produk Peternakan. Pusat Penelitian dan Pengembangan Peternakan, Bogor. 
Yuningsih, T. B. Murdiati, dan S. Juariah 2004. Keberadaan residu antibiotika tilosin (golongan makrolida) dalam daging ayam asal daerah Sukabumi, Bogor, dan Tanggerang. Seminar Nasional Teknologi Peternakan dan Veteriner, Bogor. 